\author{
Research Article \\ www.ijrap.net (ISSN:2229-3566)
}

\title{
LICHEN GENUS USNEA IN KARNATAKA
}

Rajeshwari N. ${ }^{1}$, Archana Ramachandra Mesta ${ }^{2 *}$, Vinayaka K S ${ }^{3}$

${ }^{1}$ Associate Professor, Department of Botany, Sahyadari Science College, Shimoga, Karnataka, India

${ }^{2}$ Research Scholar, Department of Botany, Kumadvathi First Grade College, Shimoga Road, Shikaripura, Shimoga, Karnataka, India

${ }^{3}$ Associate Professor, Department of Botany, Kumadvathi First Grade College, Shimoga Road, Shikaripura, Shimoga, Karnataka, India

Received on: 18/09/19Accepted on: 04/11/19

\author{
*Corresponding author \\ E-mail: archu.mesta@gmail.com
}

DOI: 10.7897/2277-4343.110114

\begin{abstract}
Usnea is a well-known genus of lichen for its medicinal uses all over the world. The lichen genus Usnea has fruticose morphology with pendulous or erect thallus and characterized by the presence of usnic acid. The present study aims to know the diversity of Usnea in Karnataka. The genus Usnea is identified up to species level based on its morphological, anatomical and chemical characters. The different forests types in Karnataka were surveyed for the work. We recorded 6 species of Usnea from the different parts of Karnataka. The higher altitudinal regions of the temperate forests harbours rich source of Usnea.
\end{abstract}

Keywords: Karnataka, Usnea, Usnic acid, fruticose thallus

\section{INTRODUCTION}

The state Karnataka is situated in the south western part of India. The geography of Karnataka contains all types of topographical variations such as mountains, coastal areas, hills and plateaus. One of the three biological hotspots in India, Western Ghats runs through Karnataka. It is known as Sahyadri or Malenadu. The average height of Sahyadri is about 900 meters. The highest altitudinal range of $1930 \mathrm{~m}$ is observed in Mullayangiri peak of Chikkamagaluru district ${ }^{1}$. The altitudinal variation of less than $300 \mathrm{~m}$ above sea level to an average of $1500 \mathrm{~m}$ is observed here.

The state Karnataka is blessed with magnificent amount of forests. It includes different types of forests such as Evergreen and semi-evergreen forests, moist deciduous, dry deciduous and thorny forests. Lichens are the unique organisms with the combination of both algae and fungi. The rich growth of lichens can be seen in most tropical forests. The study of lichens in south India is mainly focused in Nilgiri and Palani hills ${ }^{2,3}$. Only a little knowledge is known about the diversity of lichens in Karnataka $^{4-8}$.

The lichen genus Usnea belonging to the family Parmeliaceae is a lichenized ascomycetes consisting of more than 350 species all over the world ${ }^{9}$. Usnea is fruticose lichen with pendulous or erect thallus, which can be easily identified by its thread like morphology. The pigmentation of the basal part of the thallus, cortex and medulla, shape and type of branching are some of the morphological characters which don't change with the change in geographical area. The present study aims at the categorization of all the Usnea species of Karnataka.

\section{MATERIAL AND METHODS}

The present study is based on the collections made from August 2014 to December 2016. The survey was carried out in different parts of Karnataka, such as Shimoga, Chikkamagaluru, Uttara Kannada, Dakshina Kannada, Udupi, Dharwad, Belgaum, Gadag, Haveri, Ballary, Chitradurga, Davanagere, Tumkuru, Chikaballapura, Kolara, Mysore, Chamarajnagar and Kodagu districts, India.

The collected samples were taken to the laboratory, air dried and stored in lichen herbarium of K.F.G.C., Shikaripura. The voucher specimen number LHKFGC0001 to LHKFGC0042 were collected during the present work and are identified up to species level. The $\mathrm{P}^{\mathrm{H}}$ of the substrate trees was identified. The ecological parameters such as temperatures, humidity, altitude, latitude were noted at the place of collection. The morphological characters are noted down. The anatomical characters studied with the help of binocular microscope. The chemical tests are carried out to identify the secondary metabolites present in $i^{10,11}$. The identification of Usnea was done on the basis of morphological, anatomical and chemical characters ${ }^{12,13}$.

\section{RESULT AND DISCUSSION}

Usnea was collected in different localities of Karnataka. The collected Usnea are identified as 6 different species based on it anatomy, morphology and colour test (Table 2). All the Usnea species collected were found in the temperate forests that is evergreen and semi-evergreen forests of the state. The deciduous and scrubby forests have no traces of Usnea. The Usnea species were collected at the altitudinal range of $600 \mathrm{~m}$ to $2350 \mathrm{~m}$ (Table 1). More number of Usnea thallus was found in the higher altitudinal region of $2350 \mathrm{~m}$ that is in Mullayyangiri of Chikmagaluru district. Only few thallus were observed in lower altitudinal region.

The present study reveals that the Karnataka state harbours 6 species of Usnea lichens (Plate 1 and Plate 2). More number of lichens was collected from temperate forests of higher altitudinal 
region. The diversity of Usnea lichens in Karnataka state is rich when compared to diversity of nearby states Goa and Maharashtra ${ }^{14}$. But the states of Kerala and Tamil Nadu shows very rich diversity of Usnea lichens when compared to Karnataka ${ }^{4,15,16}$.

\section{CONCLUSION}

Karnataka is a state with rich biodiversity. The state is surrounded by different types of forests. Usnea Adans. is a large genus in the family Parmeliaceae, with more than 350 species that are widely distributed in polar, temperate and tropical regions. The present work showed the occurrence of 6 species of Usnea. Among them $U$. ghattensis and $U$. undulata are available in large quantity in Mullayangiri. The other 4 species are found with very few thallus. The largely available species can be sustainably used for their economical purposes.

Table 1: Usnea collected from different localities with altitude and substrate

\begin{tabular}{|c|c|c|c|c|}
\hline S. No. & Name & Locality & Altitude (m) & Substrate \\
\hline 1 & Usnea ghattensis & $\begin{array}{l}\text { Karnataka, Dakshina kannada dist. Sullia, } \\
\text { Karnataka, Chikmagaluru dist. Mullayangiri }\end{array}$ & $\begin{array}{l}1900 \\
2350\end{array}$ & Tree \\
\hline 2 & Usnea leucospilodea & Karnataka, Shimoga, Sagar, Sharavati River basin, Mattikoppa & $603 \mathrm{~m}$ & Fallen twig \\
\hline 3 & Usnea luridorufa & $\begin{array}{c}\text { Karnataka, Dakshina Kannada, Sulllia, Subramanya } \\
\text { Kumaraparvata }\end{array}$ & $1200 \mathrm{~m}$ & Bark \\
\hline 4 & Usnea orientalis & $\begin{array}{l}\text { Karnataka, Chikkamagaluru Dist. } \\
\text { Kemmangundi, }\end{array}$ & $1000 \mathrm{~m}$ & Bark \\
\hline 5 & Usnea rigidula & Karnataka, Dakshina kannada dist. Subramanya, Kumaraparvata & $1500 \mathrm{~m}$ & On stones/ bark \\
\hline 6 & Usnea undulata & Karnataka, Chikmagaluru dist. Mullayangiri & $2340 \mathrm{~m}$ & stones \\
\hline
\end{tabular}

Table 2: The result of colour tests shown in collected $U$ snea species

\begin{tabular}{|c|c|c|c|c|}
\hline \multirow{2}{*}{ S. No. } & \multirow{2}{*}{ Species name } & \multicolumn{3}{|c|}{ Colour test } \\
\cline { 3 - 5 } & & K test & K test & K test \\
\hline 1 & Usnea ghattensis & - & - & - \\
\hline 2 & Usnea leucospilodea & + & + & - \\
\hline 3 & Usnea luridorufa & + & + & - \\
\hline 4 & Usnea orientalis & + & + & - \\
\hline 5 & Usnea rigidula & + & + & - \\
\hline 6 & Usnea undulata & - & - & - \\
\hline
\end{tabular}

PLATE 1
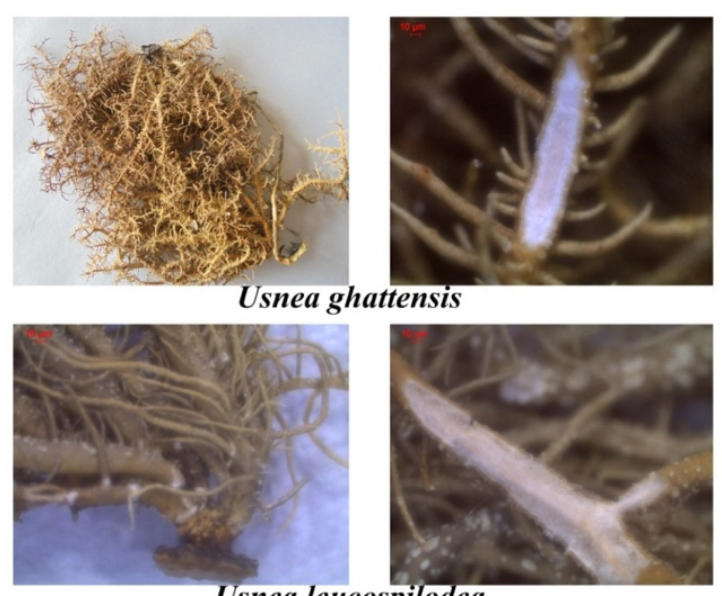

Usnea leucospilodea
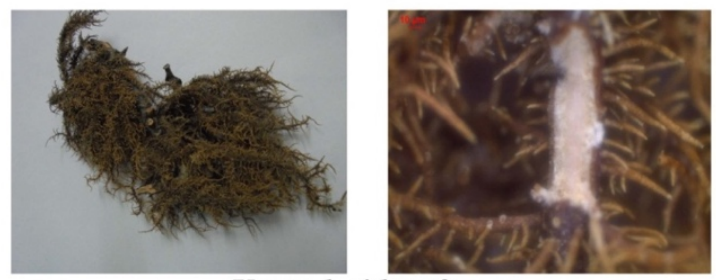

Usnea luridorufa
PLATE - 2
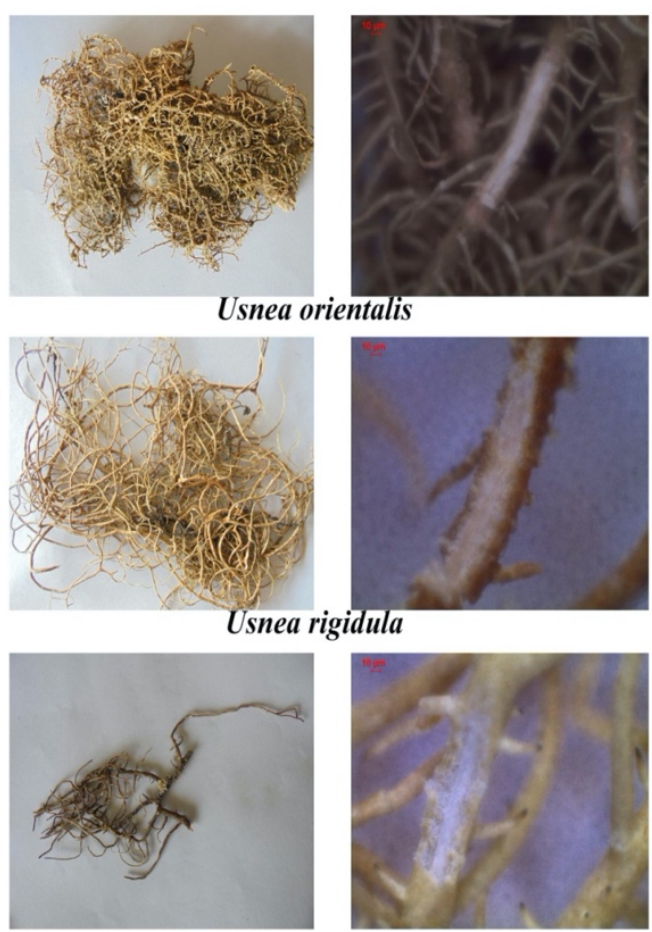

Usnea undulata 


\section{REFERENCES}

1. Erikson OE. Outline of Ascomycota. Myconet 2005; 11: 1113.

2. Awasthi DD. A new species of Parmelia from Kodaikanal, South India. Curr. Sci 1957; 26: 123-124.

3. Awasthi DD. In: A Compendium of the Macrolichens from India, Nepal and Sri Lanka. Bishen Singh Mahendra Pal Singh Publishers and Distributors of Scientific Books, Dehra Dun, India; 2000. p. 1-580.

4. Muktesh Kumar and Stephen S. Lichen flora of Western Ghats: An Appraisal 1997; 21(1): 27-39.

5. Nayaka S and Upreti DK. Lichens flora of Sharavathi River Basin, Shimoga district, Karnataka, India, with six new records. Journal of Economic and Taxonomic Botany 2002; 26(3): 627-648.

6. Balaji $P$ and Hariharan GN. Lichen diversity and its distribution pattern in tropical dry evergreen forests of Guindy National Park (GNP), Chennai. Indian Forester 2004; 130 (10): 1155-1168.

7. Vinayaka KS, Krishnamurthy YL and Nayaka S. Macrolichen flora of Bhadra Wildlife Sanctuary, Karnataka, India. Annuals of Forestry 2010; 18(1): 81-90.

8. Vinayaka KS, Shravanakumara S, Kumaraswamy Udupa ES and Krishnamurthy YL. Diversity of Epiphytic Lichens and Evaluation of Important Host Species Exploited by Them in Tropical Semi-Evergreen and Deciduous Forests of Koppa, Central Western Ghats, India. The Asian and Australasian Journal of Plant Science and Biotechnology 2011; 5(1): 6266.
9. Clerc P. Species concept in the genus Usnea (lichenized Ascomycetes). Lichenologist 1998; 30(4-5): 321-340.

10. White FJ, James PW. A new guide to the micro chemical technique for the identification of lichen substances. British Lichen society Bulletin 1985; 57: 1-41.

11. Orange A, James PW, White FJ. Micro chemical methods for the identification of lichen products. British lichen society, London; 2001. p. 101-103.

12. Awasthi DD. A Compendium of the Macro lichens from India, Nepal and Sri Lanka. Bishen Singh Mahendra Pal Singh, Dehra Dun, India; 2007. p. 1-580.

13. Ohmura Y. A synopsis of lichen genus Usnea (Parmeliaceae, Ascomycota) in Taiwan. Mem Natl. Mus. Nat. Sci., Tokyo 2012; 48: 91-103.

14. Mesta AR, Vinayaka KS, Rajeswari N. Distribution Pattern and ecology of Usneoid lichens in Western Ghats, Southern India. J New Biological Reports 2015; 4(3): 247-254.

15. Shyam Kumar R, Thajuddin N, Upreti DK. Diversity of lichens in Kollihaills of Tamil Nadu, India. International Journal of Biodiversity and Conservation 2011; 3(2): 36-39.

16. Nayaka S. and Upreti DK. Status of Lichen Diversity in Western Ghats. http:/wgbis.ces.iisc.ernet.in/biodiversity/ sahyadri/lichens; 2006.

\section{Cite this article as:}

Rajeshwari $\mathrm{N}$ et al. Lichen genus usnea in Karnataka. Int. J. Res. Ayurveda Pharm. 2020;11(1):72-74 http://dx.doi.org/10.7897/2277-4343.110114 the site content and articles published. The views expressed in articles by our contributing authors are not necessarily those of IJRAP editor or editorial board members. 